\title{
PREPAREDNESS OF EDUCATORS TO IMPLEMENT MODERN INFORMATION TECHNOLOGIES IN THEIR WORK WITH PRESCHOOL CHILDREN
}

\author{
Dr. Sonja Veličković, College for Preschool Teachers, Aleksinac, Serbia \\ E-mail: sonja velickovic@gmail.com \\ Dr. Lazar Stošić, College for Preschool Teachers, Aleksinac Serbia \\ E-mail: 1stosic@vsvaspitacka.edu.rs
}

\author{
A R T I C L E I N F O \\ Original Article \\ Received: April, 28.2016. \\ Revised: June, 01.2016. \\ Accepted: June, 05.2016. \\ doi:10.5937/IJCRSEE1601023V \\ UDK \\ 004:373.21(497.11) \\ 371.694
}

Keywords:

modern Information Technologies,

educator,

professional pedagogical and methodological competence, professional development.

\begin{abstract}
A B S T R A C T
This study explores the issue of the preparedness of educators to realize the contents of the PPP (Preschool Preparatory Program) from the point of view of digitalization and informatization of the society The authors are in favour of the implementation of modern educational technology in the process of educating preschool children with the aim of improving the quality of educational work. By this we primarily mean the use of computers and didactic programs in kindergartens which are seen as institutions which carry out a systematic and planned education of preschool children. With this objective have the results of the research of the degree to which the educators are prepared to use computer in the process of realization of the contents of the Preparatory preschool program been presented. The results show that educators are interested in implementing ICT (Information and Communication Technology) within the process of educating preschool children who live and grow up in an era of Information Technology. The use of computers can surely help in the process of realization of the contents of the Preparatory Preschool Program; however, the truth is that they are not properly trained and qualified to do so, or to be more precise, they do not possess adequate pedagogical and methodological competence to be able to implement modern Information Technologies in their work with preschool children.
\end{abstract}

(C) 2016 IJCRSEE. All rights reserved.

\section{INTRODUCTION}

The implementation of modern technologies is becoming an essential part of modern education. Global exchange of information, movement towards the informatics system, as well as numerous tendencies of modern technologies, bring about the need to adjust the educational system and with that also the educators' environment. The changed role of educators in the era of digitalization has become the imperative of the society and their life-

Corresponding Author

Dr. Sonja Veličković, College for Preschool Teachers, Aleksinac, Serbia

E-mail: sonja velickovic@gmail.com

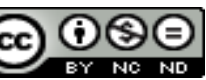

This work is licensed under a Creative Commons Attribution 4.0 International license. The article is published with Open Access at www.ijcrsee.com long learning and professional development have become the priority. Professional development of educators implies "... the raising of consciousness of educators in terms of what, how and in what way they can improve the educational process" (Stošić and Veličković, 2011:305).

The quality of educational work with preschool children can be improved and become better by means of studying the possibility of implementing Information and Communication Technologies and especially by means of focusing on the importance of the possibility of implementing modern education technology in the process of educating preschool children. Familiarization with the great creative potential which Information Technology possesses in the process of raising the quality of educational work, represents motivational factor which can encourage educators to broaden their informatic knowledge.

The implementation of Information 
Technology in preschool education should be realized through its application and integration within the educational work of educators, the main aim of which would be to create numerous possibilities of significant improvement of the quality of educational work and maximum involvement of children in the learning process. The use of ICT in work with preschool children is difficult to accept and the reason for that is most frequently the lack of education and information on the part of educators (Stošić, 2011), as well as the fear of the unknown. Within educational activity all over the world, as well as in our country, the introduction of various innovations is still facing strong resistance of educators' traditionalism, indifference and inertness and it also provokes fear, rejection and irrational hostility. Up to a certain point, this is even understandable because older generations of educators were not trained to use modern technology in preschool teaching. Unlike older generations, new generations are coming fully or partially prepared to properly guide children into the world in which computers are used, and those computers are becoming their everyday companions. Thus "... as educators improve their knowledge related with the use of various technologies, the accompanying hardware equipment and with programs that can be used in their work with children, they will gain more confidence in their work, broaden their horizons in terms of possibilities offered by new media and Information and Communication Technologies and increase creativity with their implementation in everyday educational work." (Arsenijević and Andevski, 2011:29).

The mastering of basic skills related with operating a computer on the part of educators is the priority which precedes the introduction of Information Technology into educational work and the development of technical culture of preschool children. However, the first obstacle turned out to be the preconceptions regarding the age of educators and their insufficient knowledge related with the use of computers. Although older educators guess the possible usefulness and purpose of the use of Information Technology, the younger ones are aware of its benefits, especially when it comes to handling pedagogical documentation, professional development and obtaining information; however, they do not have programs and sufficient equipment for educational work.

The new media and the ICT can, if used, fundamentally change the system and the design of educational work, which is why their proper implementation requires pedagogical knowledge of working with children in such conditions, as well as the knowledge of the methodology of their use.

That is the reason why, in recent years, more attention has been paid to the training of future educators in terms of introducing Information Technologies into the educational system. In Preschool Teacher Training Colleges of Vocational Studies, there are subject programs within the field of Information Technology which require user-level knowledge acquisition (operative system, Internet, text processing programs, drawing programs, presentation-making programs, video and sound processing programs, getting to know the ready-made educational software, the use of various hardware components - printer, scanner, cameras, etc.).

\subsection{Professional Competence of Educators in Implementing Modern Information Technologies}

Modern Information Technologies have found their use in all the spheres of society, including the sphere of education. Within new educational technologies, multimedia didactic programs represent the treasury of teaching aids and resources which contribute to the modernization of educational work.

The changes in Information Technologies and changes within the society caused by those changes, recognize that educators should be able to modernize their work and to acquire new competence. New competence refers to informatic knowledge necessary in the $21^{\text {st }}$ century, which means that educators should be able to make didactic materials independently in electronic form and use computers more often as a modern tool in the process of realization of program contents with preschool children, replacing overhead projectors, tape recorders, slide projectors, movie projector, episcopes and other obsolete devices and aids.

A $21^{\text {st }}$ century educator should have professional, pedagogical and methodological competence. As stated by Arsenijević \& Andevski, ,expert ICT competences are those competences of educators which are necessary for the direct use of these technologies in teaching or otherwise and for their areas of application. Pedagogical and methodological competences are those competences which enable educators to use new media and technologies in their work with children in an ad- 
equate way, as teaching aids, as well as teaching subjects" (Arsenijević and Andevski 2011: 28).

Pedagogical intuition, sensibility, creativity and computer literacy are all qualities of crucial importance for educators' profession, which is why they should be constantly improved and developed through a permanent learning process, cooperation with colleagues, parents and most importantly with children. In their work with children educators must be able to use computers and computer programs, but they can also create computer programs because only they have practical experience working with children.

With the aim of developing professional competence of educators for the purpose of achieving better quality of their work and further professional development, as Grandić and Stipić state "professional development should be seen as a requirement of general importance for the profession, as well as an inner need of an individual" (Grandić and Stipić, 2011:199). Apart from that, educators have the obligation to attend and participate in seminars approved by the Ministry of Education listed in the Catalogue of the Program for Professional Development of Teachers, Educators and Associates. The first issue of the Catalogue of the Program for Professional Development of Teachers, Educators and Associates started being used during the school year $2006 / 2007$ and it was published every year, but starting from the school year 2012/2013, the Catalogue is authorized every two years and it is only available in electronic form. Everyone working in the area of education, has the obligation to achieve 120 points in a period of five years - 100 points for attending the approved programs, ( 60 hours from the list of mandatory subjects and 40 hours from the list of elective ones), and up to 20 points for participating in approved professional seminars (Article 12. of the Law on the Basics of Educational System, 2013).

Based on the analyses of the Catalogue, it can be concluded that the number of accredited programs is increasing year after year, including the area of preschool education. The first issue of the Catalogue of the Program for Professionals in the Area of Education included a total of 173 accredited programs, 7 of which were related with the area of preschool education, whereas the Catalogue of the Program for Professional Development of Professionals in the Area of Education for the school years 2012/2013 and 2013/2014 included 1021 accredited programs, 80 of which were related with the area of preschool education.

In terms of the accredited programs related with training educators to use Information Technologies in their work with preschool children, we can say that there is a really paradoxal situation there, namely, there was no accredited program with the stated topic in the first issue of the Catalogue. The next issue of the Catalogue for the school year 2007/2008, had one accredited program named "Child in the World of Computers", and all the following issues of the Catalogue contained the "Virtual Kindergarten" accredited program as a mandatory program. According to the statistics of the Institute of Improvement and Development of Education, for the school year 2011/2012, there were three seminars, and a total of 47 educators attended the "Virtual Kindergarten" accredited program. In the school years 2012/2013 and 2013/2014 and up to the present moment, there was no interest whatsoever. This tells us that the issue of introducing modern Information Technologies in preschool education is not treated with much enthusiasm, and that there is no "sound and systematic support to the professional development of educators with the aim of realizing Preparatory Preschool Program with more quality" (Veličković, 2014:120), which also implies greater degree of the ability of educators to implement modern Information Technologies in their work with preschool children.

It is obvious that our educators are, in terms of computer literacy, far behind their colleagues from EU countries. For example, the Swedish government has, in its attempt to fulfill its ambition and become IT leader in the whole world (which it actually achieved), put the introduction of new media and ICT to all levels of educational system as the top priority on the list of priorities, seeing them as an overall function which facilitates all other activities. That is the reason why the educational institutions in Sweden are highly technologically equipped, including the preschool institutions. More than half of the teaching staff (around 75,000) included in education of children and adults alike, is attending at least one kind of training provided by the government itself, and carried out with the help of specially trained informatic consultants. 


\subsection{The Implementation and Inte- gration of ICT in Educational Work with Preschool Children}

The acceptance of the specific nature of educational work with preschool children, as well as of the principles and of long-term aims in that work, requires special approach of Information Technology in preschool educational system.

Information Technology in education offers the possibility of using new methods and new organization of educational work, which would reduce the limitations of the traditional way of work to a tolerable level. Education technology should not only be understood as a simple use of computers (which is, due to numerous possibilities that they offer, inevitable nowadays), but rather as the implementation of diverse forms, ways and methods of work within the educational process which are enabled by means of various devices, such as different forms of television, videos, satellites, telecommunications, educational networks and services, optical technologies and the like (Danilović, 2010).

The implementations of Information Technologies are numerous, however, theoreticians and researchers single out three most important ones:

1. the acquisition of new knowledge the use of educational programs,

2. revision and repetition of the acquired knowledge,

3. different leisure activities: games, drawings (Rečicki and Girtner, 2002).

Children should experience enormous possibilities which Information Technologies offer. It is essential that educators use their numerous potentials and thus achieve positive effect in all the areas of child development, raise the quality of all the segments of educational work and develop media culture of children.

There were some opinions that claimed that computers are not suitable for preschool children, because they are very complex machines which require certain level of intellectual development, especially a high level of abstract thought. However, the development of the so called user-friendly approach, which is directed towards making the technology available to users, has in great measure dismantled the myth which lead us to believe that only trained adults can use them (Pribišev Beleslin, 2007:20).

Information Technology (which includes computer games) offers stimulation of the senses through pictures, sounds, tones, films etc. This kind of multimedia representation increases children's attention and speeds up the learning process. In The Basics of the Preschool Education Program it has been determined that computers have their own place in various music, art, perceptive, logic and other activities. Generally speaking, computer games are great fun for children. At a very early stage of their development, using computer programs, children discover cause and effect relations of their own actions. Didactic programs enable improvement in accordance with children's abilities, generating, at every stage that a child reaches, the feeling of competence, and with that, it encourages children's self-confidence, self-respect and self-consciousness. Playing and dealing with programs which were specifically made for them, children have the opportunity to be creative, to direct their thoughts towards finding solutions and overcoming obstacles.

\section{MATERIALS AND METHODS}

The aim of the research was to determine the level of competence of educators in terms of their ability to use computers in the process of carrying out the Preparatory Preschool Program. The tasks related with the objectives of the research were the following:

- Exploring the level of competence of educators in terms of their ability to use computers,

- Finding out whether the educators are familiar with programs from the Catalogue of the Program for Professional Development of Professionals in the Area of Education regarding the use of ICT,

- Finding out whether the educators are sufficiently trained to use computers in the process of implementing the contents of the Preparatory Preschool Program,

- Finding out to what extent the educators are interested in education within the area of education technology,

- Exploring the situation of educators with the aim of finding out whether educators have support from the director and the administration department of their preschool institution regarding the implementation of computers in their work with preschool children.

In accordance with the proposed research tasks, the following hypothesis and sub-hypothesis have been postulated. The general hypothesis of this research is: It is presumed that educators are not sufficiently 
trained and prepared to use computers in the process of realizing the contents of the Preparatory Preschool Program.

The instrument used in the research was the Likert scale, made especially for the purpose of this research; it consisted of 12 items which represented indicators of the competence of educators in terms of their ability to use ICT in their work.

The sample used in the research consisted of educators from the preschool institution "Naša radost", as well as of the educators from the preschool groups in 'Branko Radičević" primary school in Bujanovac. The research was conducted with the teaching staff at the beginning of the year 2015 .

In our sample of 50 (100\% valid sample) subjects, the value of Cronbach's Alpha Quotient $=0,805$, shows high level of reliability and internal compliance of the scale for this sample, which completely satisfies the reliability criteria.

\section{RESULTS AND DISCUSSION}

Table 1. shows the opinions of educators as to whether or not kindergartens should have IT rooms for preschool children computer training.

Table 1. Opinions of educators as to whether or not kindergartens should have IT rooms

\begin{tabular}{lcccc}
\hline & Frequency & Percentage & $\begin{array}{c}\text { Valid } \\
\text { Percentage }\end{array}$ & $\begin{array}{c}\text { Cumulative } \\
\text { Percentage }\end{array}$ \\
\hline $\begin{array}{l}\text { I mostly } \\
\text { agree }\end{array}$ & 11 & $22 \%$ & $22 \%$ & $22 \%$ \\
\hline I agree & 25 & $50 \%$ & $50 \%$ & $72 \%$ \\
\hline $\begin{array}{l}\text { I totally } \\
\text { agree }\end{array}$ & 14 & $28 \%$ & $28 \%$ & $100 \%$ \\
\hline Total & 50 & $100 \%$ & $100 \%$ & \\
\hline
\end{tabular}

The results above show that 11 educators $(22 \%)$ mostly agree, 25 educators $(50 \%)$ agree and 14 educators (28\%) totally agree that kindergartens should have IT rooms for preschool children computer training.

The obtained results show that educators are very interested in having an IT room in their kindergartens for preschool children computer training.

Graph 1. shows the results of the claim which states that Educators are not sufficiently trained and prepared to use computers in the process of realizing the contents of the Preparatory Preschool Program".

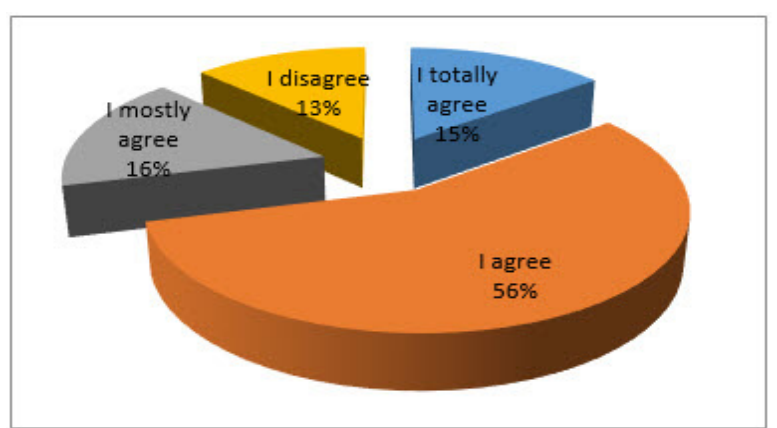

Graph 1. Opinions of educators related with their computer competence in the process of realizing the contents of the Preparatory Preschool Program

Out of the total number of subjects, 31 educators, that is $62 \%$ of them agree that educators are not sufficiently trained and prepared to use computers in the process of realizing the contents of the Preparatory Preschool Program, 9 educators responded that they mostly agree, which represents $18 \%$ of subjects, 8 subjects totally agree with the claim, whereas only 2 educators disagree with the claim stating that educators are not sufficiently trained and prepared to use computers in the process of realizing the contents of the Preparatory Preschool Program.

Chi-squared test $=7.654$, obtained by means of statistical analyses, for 6 degrees of freedom, $p=0,265$, which is not statistically significant, indicates that educators are not sufficiently trained and prepared to use computers in the process of realizing the contents of the Preparatory Preschool Program. If we take into account the level of education, we can conclude that the results are not statistically very different.

Table 2. shows the structure of samples according to the level of education of educators.

Table 2. The structure of samples according to the level of education of subjects

\begin{tabular}{lcccc}
\hline & Frequency & Percentage & $\begin{array}{c}\text { Valid } \\
\text { percentage }\end{array}$ & $\begin{array}{c}\text { Cumulative } \\
\text { percentage }\end{array}$ \\
\hline College & 20 & $40 \%$ & $40 \%$ & $40 \%$ \\
\hline University & 18 & $36 \%$ & $36 \%$ & $76 \%$ \\
\hline $\begin{array}{l}\text { Applied } \\
\text { Studies }\end{array}$ & 12 & $24 \%$ & $24 \%$ & $100 \%$ \\
\hline Total & 50 & $100 \%$ & $100 \%$ & \\
\hline
\end{tabular}

Out of the total number of subjects in the study, 20 (40\%) subjects had a college degree, 18 educators, that is $36 \%$, had a university degree and 12 subjects, or $24 \%$ of them, had obtained the Applied Studies degree for preschool teachers. 
Graph 2. shows the structure of the samples according to the years of service of educators.

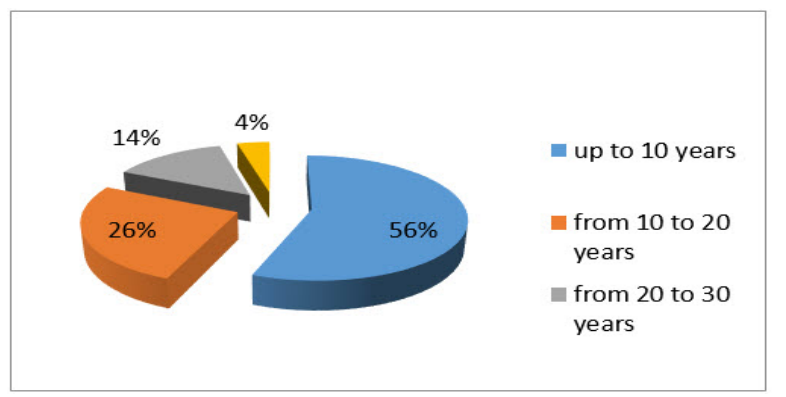

Graph 2. Structure of the samples according to the years of service of the subjects

When it comes to the years of service, the greatest number of subjects $(56 \%)$ belongs to the category of lowest number of the years of service, up to 10 years, $26 \%$ of educators belong to the category 10-20 years of service, $14 \%$ educators belong to the category $20-30$ years of service and $4 \%$ of educators are those with more than 30 years of service.

We believe that "younger" educators, younger in terms of years of service, agree more that computers should be used, because younger generations live and grow in a digitalized environment, which is why they are more open to and also use more, on a daily basis, some of the forms of modern Information Technologies (social networks, e-banking, chip IDs and cards, etc.), and are thus aware of the usefulness of computers when it comes to educational work. Therefore, this research showed that "younger" educators, younger in terms of years of service, have positive attitude towards modern Information Technologies.

Graph 3. shows the results of the opinion of educators related with the issue of whether or not educators are familiar with programs of education technology from the Catalogue of the Program for Professional Development of Professionals in the Area of Education, regarding the use of ICT.

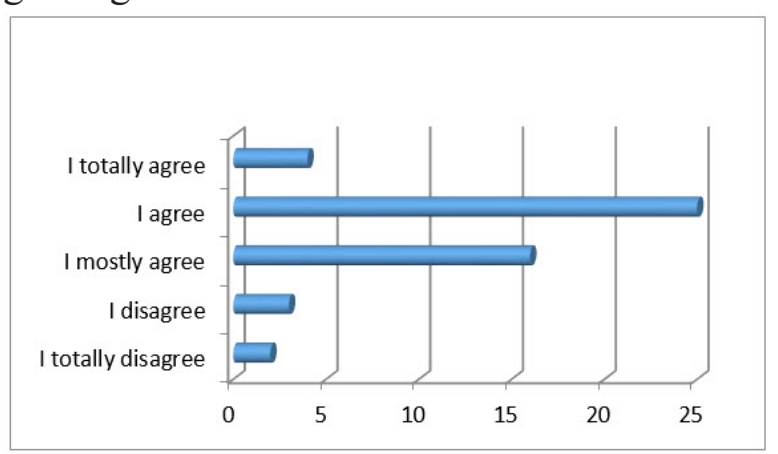

Graph 3. Educators are familiarized with programs of education technology from the Catalogue of the Program for Professional Development of Professionals in the Area of Education

Regarding the results related with the claim that "Educators are familiar with programs of education technology from the Catalogue of the Program for Professional Development of Professionals in the Area of Education ", 25 educators, or $50 \%$ of them, agree that educators are familiar with programs of education technology from the Catalogue of the Program for Professional Development of Professionals in the Area of Education. Sixteen educators responded that they mostly agree, which represents $32 \%$ of subjects. Four educators, or $8 \%$ of them, totally agree, 3 educators, or $6 \%$ of them disagree, whereas 2 subjects, or $4 \%$ of them totally disagree with the claim that educators are familiarized with programs of education technology from the Catalogue of the Program for Professional Development of Professionals in the Area of Education.

The presented results show that most of the subjects agree with the claim which states that educators are familiar with programs of education technology from the Catalogue of the Program for Professional Development of Professionals in the Area of Education. The results are certainly encouraging, because they indicate that educators are interested in their own education and professional development.

Chi-squared test $=14.051$, obtained by means of statistical analyses, for 8 degrees of freedom, $p=0,080$, which is not statistically significant, indicates that educators are familiar with programs of education technology from the Catalogue of the Program for Professional Development of Professionals in the Area of Education.

Graph 4. shows the results of the opinion of educators regarding the issue of the extent to which educators are interested in implementing ICT in kindergartens.

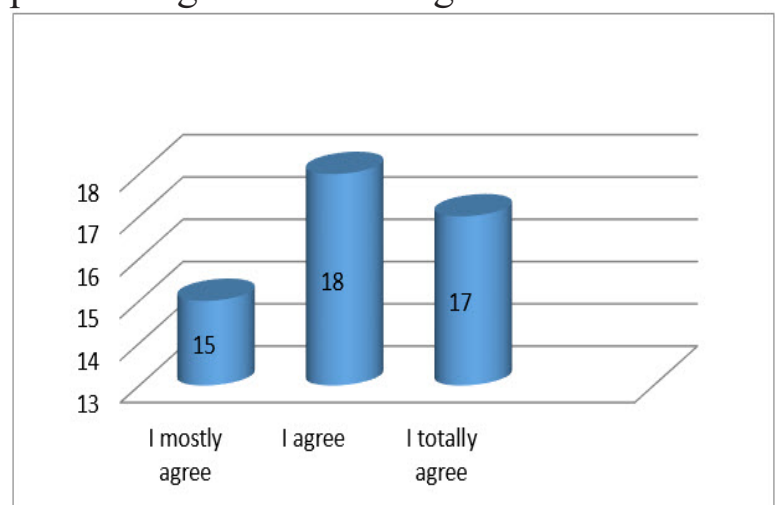

Graph 4. Interest of educators regarding the implementation of ICT in kindergartens 
The obtained results related with the claim that "Educators are interested in education within the area of Information Technology" showed that 21 educators, or $42 \%$ of them, agree that educators are interested in education within the area of Information Technology. Twelve educators responded that they mostly agree, which represents $24 \%$ of the subjects, and 17 educators, or $34 \%$ of them, totally agree with the claim that educators are interested in education within the area of Information Technology.

The results clearly show that educators are very interested in implementing ICT in kindergartens.

Chi-squared test $=5.806$, obtained by means of statistical analyses, for 4 degrees of freedom, $p=0,214$, which is not statistically significant, indicates that educators are interested in education within the area of Information Technology.

Graph 5. shows the results related with the claim that "Educators have the support of the director and the administration department of their preschool institution regarding the implementation of computers in their work with preschool children".

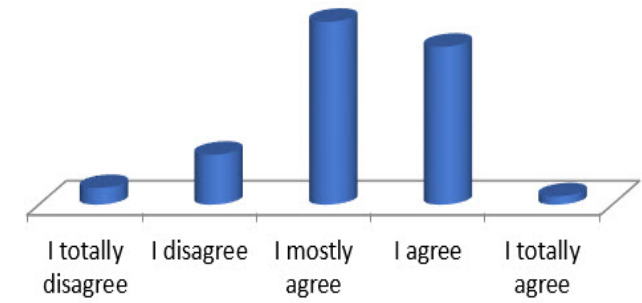

Graph 5. Opinions of educators related with the issue of whether or not educators have support from the director and the administration department of their preschool institution regarding the implementation of computers in their work with preschool children

The obtained results related with the claim that "Educators have support from the director and the administration department of their preschool institution regarding the implementation of computers in their work with preschool children", show that 19 educators, or $38 \%$ of them, agree with the claim that educators have support from the director and the administration department of their preschool institution regarding the implementation of computers in their work with preschool children. Twenty-two educators responded that they mostly agree, which represents $44 \%$ of subjects. One educator, or $2 \%$ of them, totally agrees, whereas 6 educators, or $12 \%$ of them disagree with the claim which states that educators have support from the director and the administration department of their preschool institution regarding the implementation of computers in their work with preschool children.

Chi-squared test $=15.659$, obtained by means of statistical analyses, for 8 degrees of freedom, $p=0,048$, which is not statistically significant, indicates that educators have support from the director and the administration department of their preschool institution regarding the implementation of computers in their work with preschool children.

\section{CONCLUSION}

Using theoretical research and analyses of the attitudes of educators regarding the implementation of modern Information Technologies in their work with preschool children, we wanted to find out opinions of educators as to whether the use of computers can help in the process of realization of the contents of the Preparatory Preschool Program.

If we compare the results of this research with the results of previous ones, which the author, Stošić (2011), conducted with students who had rich working experience in preschool institutions, and who were attending the College of Vocational Studies for Preschool Teachers in Aleksinac for the sake of receiving additional education, we can conclude that the competence of educators in terms of their ability to implement ICT in their work with preschool children is at a very low level.

If we add to that the fact that professional development of educators through informal forms of education, mostly training programs and projects aimed at implementing the modern Information Technology in educational work is not present enough, we can reach the conclusion that educators do not possess sufficient professional pedagogical and methodological competences in the area of realizing the contents of the Preparatory Preschool Program which confirms the postulated hypothesis. This thesis is also supported by a one-time training through Virtual Kindergarten accredited program which the educators from the preschool institution "Naša Radost" from Bujanovac had in 2013, which implies that educators need continuous and systematic support in the area of ICT, in order for them to be able to use all the advantages of the ICT, and also facilitate their everyday work in the 
process. Above everything else, the number of professional seminars in which educators will have to prove or improve their knowledge should be increased.

The encouraging fact in our research is that educators are not passive when it comes to implementing computers in the process of realizing the contents of the Preparatory Preschool Program; they are rather interested in having an IT room for informatic training of preschool children in their institutions and most of the subject agree on that.

A successful implementation of Information Technologies within the system of educational work depends, primarily, on the awareness and responsibility of educators themselves regarding their very usefulness, for both professional development and technical culture of children.

\section{ACKNOWLEDGMENTS}

Special thanks to the educators from the preschool institution "Naša radost", as well as of the educators from the preschool groups in "Branko Radičević" primary school in Bujanovac. for their organizational help with this project. Also, we would like to thank Daniela Kraljić, the director of "Educamentis centar" from Niš for their translation and proofreading services.

\section{Conflict of interests}

The authors declare no conflict of interest.

\section{REFERENCES}

Arsenijević, J., Andevski, M. (2011). Kompetencije vaspitača za upotrebu novih medija i tehnologija, Zbornik Visoke škole strukovnih studija za obrazovanje vaspitača u Kikindi, br.2, 25-35.

Danilović, M. (2010). Tehnika, obrazovna tehnologija i informatika u funkciji povećanja efikasnosti obrazovnog procesa učenja, Tehnička informatika u obrazovanju, 3. Internacionalna konferencija, Čačak: Tehnički fakultet.

Grandić, R., Stipić, M. (2011). Profesionalni razvoj nastavnika-put do kvalitetnog obrazovanja, Pedagoška stvarnost, br.3-4, 198-209.

Katalog programa stručnog usavršavanja zaposlenih u obrazovanju za školsku 2012/2013. i 2013/2014., Beograd: Zavod za unapređivanje vaspitanja i obrazovanja, dostupno na: http:// www.zuov.gov.rs/novisajt2012/index.html

Pribišev Beleslin, T. (2007). Susretanje u elektronskom svetu: Deca, vaspitači, kompjuteri, vrtići, Banja Luka: Fakultet društvenih nauka.

Rečicki, Ž., Girtner, Ž. (2002). Dete i komjuter, Beograd: Zavod za udžbenike i nastavna sredstva.

Veličković, S. (2014). Profesionalni razvoj vaspitača u funkciji unapređivanja kvaliteta Pripremnog predškolskog programa, Pedagoška stvarnost, LX.(1), 112-121.

Zakon o osnovama sistema obrazovanja i vaspitanja, (,Sl.glasnik RS“, br. 52/2011 i 55/2013).

Stošić, L., Veličković, S. (2011). Education and professional development of educators of preschool education, Инновационный потенциал субъектов образовательного пространства в условиях модернизации образования, Россия, Ростов-на-Дону, рр. 305-312.

Stošić, L. (2011). Pripremljenost vaspitača u oblasti tehničkog i informatičkog obrazovanja, Tehnologija, informatika $i$ obrazovanje za društvo učenja i znanja, Cačak:Tehnički fakultet dostupno na: http://www.ftn.kg.ac.rs/konferencije/tio6/radovi/7)\%20Tehnicko\%20i\%20 informaticko\%20obrazovanje/PDF/703\%20 Lazar\%20Stosic.pdf

Каталог програма сталног стручног усавршавања наставника, Retireved from http://www.zuov. rs/programil/Odrzani.aspx 